\title{
Generating and Mapping Amazonian Urban Regions Using a Geospatial Approach
}

\author{
Pablo F. Cabrera-Barona ${ }^{1, *}{ }^{\mathbb{C}}$, Manuel Bayón ${ }^{1} \mathbb{C}$, Gustavo Durán ${ }^{1}$, Alejandra Bonilla ${ }^{1}$ and \\ Verónica Mejía ${ }^{2}$ (D) \\ 1 Department of Public Affairs-Urban Studies, Facultad Latinoamericana de Ciencias Sociales-FLACSO, \\ 170135 Quito, Ecuador; mjimenezfl@flacso.edu.ec (M.B.); gduran@flacso.edu.ec (G.D.); \\ abonillafl@flacso.edu.ec (A.B.) \\ 2 Research Group on Energy, Territory and Society, Department of Geography, \\ Autonomous University of Barcelona, 08193 Bellaterra, Spain; veronicaelizabeth.mejia@e-campus.uab.cat \\ * Correspondence: pfcabrera@flacso.edu.ec; Tel.: +593-2-294-6800
}

Received: 12 June 2020; Accepted: 15 July 2020; Published: 17 July 2020

\begin{abstract}
Urban representations of the Amazon are urgently needed in order to better understand the complexity of urban processes in this area of the World. So far, limited work that represents Amazonian urban regions has been carried out. (2) methods: Our study area is the Ecuadorian Amazon. We performed a K-means algorithm using six urban indicators: Urban fractal dimension, number of paved streets, urban radiant intensity (luminosity), and distances to the closest new deforested areas, to oil pollution sources, and to mining pollution sources. We also carried out fieldwork to qualitatively validate our geospatial and statistical analyses. (3) results: We generated six Amazonian urban regions representing different urban configurations and processes of major cities, small cities, and emerging urban zones. The Amazonian urban regions generated represent the urban systems of the Ecuadorian Amazon at a general scale, and correspond to the urban realities at a local scale. (4) conclusions: An Amazonian urban region is understood as a set of urban zones that are dispersed and share common urban characteristics such a similar distance to oil pollution sources or similar urban radiant intensity. Our regionalization model represents the complexity of the Amazonian urban systems, and the applied methodology could be transferred to other Amazonian countries.
\end{abstract}

Keywords: amazon; urbanization; regions; luminosity; fractal dimension; k-means

\section{Introduction}

In recent years, diverse geographical representations have emerged to explain contemporary urbanization [1]. Traditional urban hinterlands have been rearranged through the development of new economic spaces, the expansion of land-use systems that extract natural resources, and the commodification of natural spaces in the logic of capitalist urbanization [2]. These important transformations of urban systems have also emerged in the Amazon region. Indeed, the Amazon region has been named "urban jungle" since 1980, due to its high proportion of urban residents in comparison with the rural population [3,4]. Previous research has identified a rural-urban mobility associated with urbanization processes in the Amazon, one that is facilitated by the creation of roads for extractive activities. This mobility has important socioeconomic, environmental, and political implications for countries such as Ecuador or Brazil [5]. Although Amazonian cities share some similar characteristics, they can vary greatly in their local histories, ages, and location in the Amazon [3].

The Amazon basin encompasses different South American countries and its forests are the main terrestrial stores of biodiversity and carbon in the World [6]. To the west of the Amazon basin, 
from southern Peru to southern Venezuela, there are areas with mega-diverse forests and practically no infrastructure [7]. These forests are crucial for mitigating the effects of climate change and their monitoring should be a priority for sustainable land use [8]. However, the Amazon is facing several socio-environmental problems such as deforestation and expansion of agriculture. It is estimated that by $2050,40 \%$ of the Amazon's forests will be replaced by agricultural land, releasing a massive amount of carbon into the atmosphere [9]. Changes in land use and logging, in the context of global climate change, are also factors that make the Amazon's forests more vulnerable, and these factors have several consequences affecting the human population, such as flooding, an increase in certain health problems, and a reduced availability of clean water [10].

The Ecuadorian Amazon (including the "Amazonia Alta", the woodlands of the eastern hillsides of the Tropical Andes) is considered one of the hotspots of biodiversity in the World, and includes the richest Amazon tropical forests in amphibians, birds, mammals, and vascular plants $[7,11]$. In this part of the Amazon, cities have developed along the rivers, and pioneer urban areas have emerged. This process of urbanization in many rural communities is due to population growth and the consequential development of a basic urban infrastructure [12]. Increasing the number of roads and establishing an infrastructure for services can modify the expectations of farmers in the sense that they have re-evaluated their way of life and now move between and within urban areas [13]. In this way, new urban areas have appeared in the Amazon throughout the last decades.

It is important to mention that in order to describe Amazonian urban systems, the central place theory is limited because these systems have important variations in terms of morphology, function, and extra-regional links $[14,15]$. The different processes of urban expansion have created a variety of urban shapes, micro-regional organizations, and countryside-city hybrid relationships that demand new approaches beyond the urban-rural dichotomy [5,16]. Furthermore, urban residents in the Amazon participate in urban-rural networks and in the decision making regarding rural land-use [17]. Therefore, a contextual understanding of the Amazonian cities is necessary, in which the concept of the urban region can be a turning point in territorial planning that considers peri-urban areas [18]. An urban region is understood as a network of cities and peri-urban areas that may integrate rural areas too. The urban region is seen as a polycentric region, that integrates the city and the suburban hinterland [19]. As a result of urban expansion important transformations have taken place in the dynamics that generate urban-rural territories [20]. Furthermore, urban morphologies are constructed by a series of phases that can be characterized by population concentrations followed by an expansion of uses of the space through the implosion/explosion of the territory [21,22]. In this sense, urban expansion and land use transformations have led to the configuration of regional urban spaces [23-26] with an urban way of life encompassing the whole regional space.

The above-mentioned considerations open a promising field of research to re-think the urban systems in the Amazon by applying a perspective of city-and-context. Furthermore, there are still knowledge gaps regarding methods to represent and integrate diverse urban forms within systems of urban expansion. The urban structure can be understood as the number and size of urban areas [27], but also as morphological characteristics of these areas such as fractal dimension and streets composition [28-32]. However, a systematization of urban morphologies at a regional scale has been underdeveloped [33]. The importance of scale and fractal dimension to represent urban structure has been already discussed [29,30]. Fractality, for cities, means that urban zones have similar irregular shapes independently of the scale of analysis. Fractal dimension is a key indicator of urban structure and its potential functionality, and recognizes the urban space as a complex system. For instance, fractal dimension has been used to classify in different types the urban areas of the Metropolitan Area of Lisbon, including types of small and isolated built-up urban patches, dispersed patches, growth, and urban consolidation [34]. This measure can facilitate the assessment of co-evolving growth processes of urban fragmentation and consolidation that can be linked with marked social, economic, and political changes in a territory [31]. The urban space can also be represented in terms of urban structure through the streets within an urban area, which is an indicator of urban spatial entropy [28]. 
Furthermore, the streets of a city are an indicator of urban structure that can be associated with the urban impact on natural habitats surrounding the city [35].

A useful indicator of human activity and intensity of distinctively urban land use is artificial luminosity that can be obtained using Visible Infrared Imaging Radiometer Suite (VIIRS) night-time satellite images [36]. Night-time imagery is useful for delimitations of urban areas at regional and global scales [37]. The information obtained from night-time imagery is also a useful estimator of the urban population [38,39], especially for the Amazon, where census-based information is limited or incomplete [38]. In general, this indicator is linked to temporal and spatial variations of the population, their activities, and land occupation [40,41].

In the Amazon, delimitations of the urban space need to incorporate the dimension of structure and the dimension of the urban context. In the Ecuadorian Amazon complex interactions have emerged that are influenced by factors such as the presence of the oil industry [42]. The context of extractive industries have influenced urban expansion, especially due to the development of roads and the creation of new deforestation zones, and it can be said that the urban Amazon itself is a symptom of deforestation processes due to exploitation and exportation of resources [43-45]. The relationships between the areas delineated as urban and the rest of the territory are therefore associated with capitalist logics in which diverse influences (such as extractive economic activities) operationalize the territory for an urban development [21].

Additionally, in the Ecuadorian Amazon transitions of land use within an urbanization process can be observed in very small urban zones and human settlements, including indigenous urban settlements [46,47]. In this sense, it is important to generate models of Amazonian urban regions that incorporate emergent small urban areas. These emergent urban zones have appeared due to the proliferation of activities related to oil extraction, mining, and tourism that cause the dispersion of urban land uses, and an increasing number of small urban settlements that pursue economic growth $[48,49]$ and transform natural land covers [50]. The process of urban development in the Ecuadorian Amazon is relatively recent, and the integration of the Amazon region to the national economy started around one century after the rest of the nation's geographical regions $[47,51]$. The diverse Amazon dynamics presented are not de-territorialized, and they are part of the relationships between global, modern, and local Amazonian worldviews. Therefore, these spaces can offer a representation of daily life readjustments, at different territorial scales, and in between strong processes of material and symbolic exclusion [47]. In this context, urban areas of the Amazon region are less consolidated compared to urban areas of other Ecuadorian geographical regions and have limited coverage of urban infrastructures such as roads and access to basic services.

We visualize the Amazon from a multidimensional urban perspective. The objective of this study is to create and map urban regions in the Amazon of Ecuador by clustering urban zones whilst considering key indicators of urban structure (fractal dimension, streets, and urban artificial luminosity) and urban context (oil and mining activities, deforestation). By carrying out fieldwork in an Amazon city we further explored and qualitatively validated our Amazon urban regionalization. Consequently, our analysis presents a robust proposal to better understand urban structures at the scale of the Ecuadorian Amazon geographical region that could be associated with dynamics at the local level.

\section{Materials and Methods}

The study area for this research is the Amazon of Ecuador, a geographical region of 120,000 square kilometers that comprises 6 provinces: Morona-Santiago, Napo, Orellana, Pastaza, Sucumbíos, and Zamora-Chinchipe. According to the last Ecuadorian Population and Housing Census, the region had 739,814 inhabitants, $48 \%$ women and $52 \%$ men [52]. Using a population projection for 2020, the population of the Ecuadorian Amazon is estimated to be 956,699 inhabitants [53], and it is estimated that most of the Amazonian population live in urban areas. So far, Amazon territories have been represented in terms of oil industry areas, and conservation areas, and little attention has been paid to 
an urban representation of the Amazon, considering the structure, context, and distribution of urban zones. Figure 1 depicts Amazonian provinces of Ecuador and urban zones of these provinces.

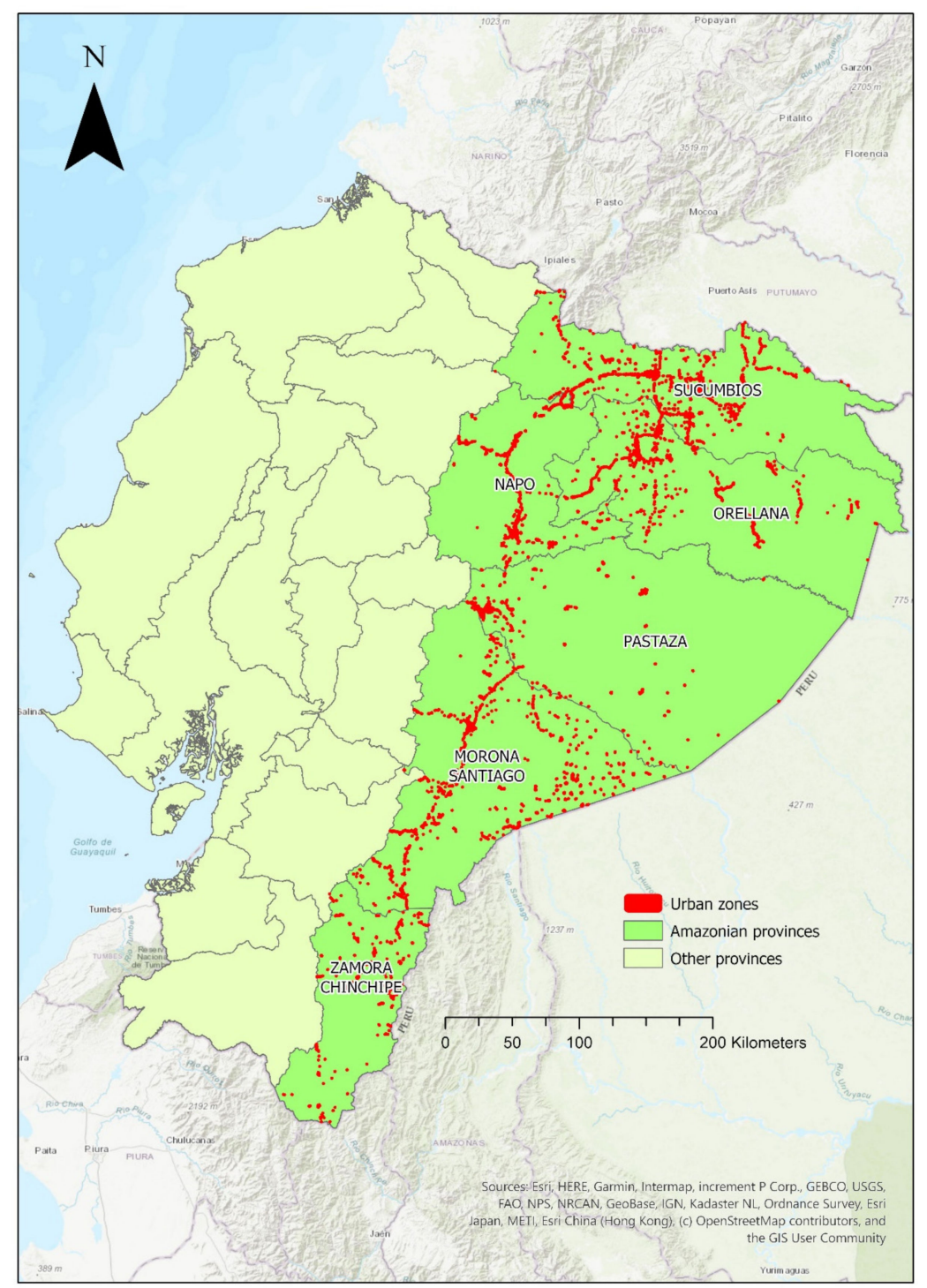

Figure 1. Study area: Provinces and urban zones of the Ecuadorian Amazon. The outline widths of the urban zones are amplified to better visualize their locations.

Information was extracted from the spatial data infrastructure platform of the Ecuadorian Ministry of Environment [54]. This platform includes geospatial information of land use-land cover, industries, and environmental monitoring. We downloaded the latest map of Ecuador's land use-land cover (2018) in shapefile format, and then extracted the 2702 urban zones corresponding to the Ecuadorian Amazon (Figure 1). The scale of the land-use information produced by the Ecuadorian Ministry of Environment is 1:100,000. Thus, the scale level corresponds to the Amazon geographical region of Ecuador. Furthermore, the Ecuadorian Ministry of Environment suggests using this scale when analyzing issues in relation of an Ecuadorian geographical region, for instance, the Amazon.

Indicators of structure and context were calculated for each one of these 2702 urban zones. The urban structure indicators used were fractal dimension, the number of paved streets, and the urban radiant intensity (urban luminosity). The number of streets for each urban zone was calculated using information produced by the Military Geographical Institute of Ecuador (scale 1:100,000), which correspond to the scale of the Amazon geographical region of Ecuador. 
To calculate the fractal dimension, the following equation was applied [55]:

$$
F=\frac{2 * \ln \left(0.25 * p_{i j}\right)}{\ln a_{i j}}
$$

where $p_{i j}$ represents the perimeter of the urban zone ij and $a_{i j}$ represents its area. This indicator has no units, and it ranges from 1 to 2, where values higher than 1 indicates a departure from Euclidean geometry, and the more the value approaches to 2, the more complex or irregular is an urban shape. An advantage of using fractal dimension is to represent the complexity of shapes, independently from spatial scale.

The urban luminosity was calculated using night-time imagery from the National Geophysical Data Center (NGDC) of the National Oceanic and Atmospheric Administration (NOAA), version 1 VIIRS day/night band (DNB) night-time lights, composed by the average of radiance values of the DNB obtained by the visible infrared imaging radiometer suite (VIIRS) of the Suomi National Polar-Orbital Partnership (SNPP) [56]. We obtained 2018 monthly imagery from the NOAA database. With these images we produced a single image of 2018 with the average of radiance. The VIIRS series of images present information about the earth's surface radiance. Each image reflects radiance values that are expressed in watts per square meter per steradian $\mathrm{W} / \mathrm{m}^{2} / \mathrm{sr}$. To compose the 2018 image, it was necessary to produce a compilation of monthly radiance values to obtain the radiances averages for 2018, and to remove observations with clouds. The monthly VIIRS imagery is composed by two images, one that reflects the radiance values and the other that presents the valid radiance registers throughout the month. Due to the presence of clouds, for some areas the radiance registers may not have been obtained during the month. Thus, these areas need to be removed from the radiance analysis through the identification of areas with no valid radiance registers, assigning to these areas null values. Thus, areas without valid registers are excluded before obtaining the radiance averages for 2018. Then, the radiance intensity was calculated for each one of the urban zones. This radiance intensity refers to the magnitude of emitted luminosity by a specific surface and it is obtained by adding the results of multiplying the different radiance values and the zones' areas in square meters that emit that radiance. The obtained results, the radiant intensity (urban luminosity), are expressed in $\mathrm{W} / \mathrm{sr}$.

The urban context indicators used are the Euclidean distances from each urban zone to the closest new deforested areas detected in 2018, to the closest oil pollution sources and to closest mining pollution sources. All in all, 6 indicators of urban structure and context were considered and used to apply a classification algorithm to cluster the 2702 urban zones of the Ecuadorian Amazon in urban regions.

Clustering algorithms can be applied as regionalization techniques. There are different regionalization techniques. Some of them consider geographical locations of the attributes (indicators) and others consider geographical locations and neighborhoods of the spatial areas where these attributes are expressed [57]. Clustering methods are unsupervised learning applied to find structure in data [58]. In this study, we applied the K-means algorithm, an algorithm that is also known as a method of geospatial regionalization [57] and is one of the most popular classification algorithms due to its simplicity, efficiency, and empirical success [58]. K-means works considering a set of $\mathrm{n}$ points with d dimensions (attributes), represented by $\left\{x_{i}\right\}, i=1, \ldots, n$. K-means divides a data set in the way that the square error between the mean $\mu_{k}$ of a cluster $c_{k}$ and the points of this cluster, is minimized. The minimization function of the square error is expressed as [58]:

$$
J(C)=\sum_{k=1}^{K} \sum_{x_{i} \in c_{k}}\left\|x_{i}-\mu_{k}\right\|^{2}
$$

The main steps of K-means are [59]:

1. To locate the centroids (centers of clusters) for each cluster based on the first partition of K clusters.

2. To assign each data point to a cluster with the nearest centroid to the point. 
3. For new clusters, calculate their centroids.

4. Repeat steps 2 and 3 until there are no changes in centroids assignation (the centroids are not "moving" anymore).

We applied the "elbow method" to define the optimal number of clusters. The "elbow method" is a practical method to determine the number classes by testing the relationships between different numbers of clusters and their sum of squared errors. The optimal K (number of clusters) is the K point ("elbow point") where a very small decrease in the error sum starts. We found the number of 6 clusters was suitable to divide the 2702 urban zones into regions, considering the 6 indicators for the classification process. We assessed the cluster validity by applying sum of squares approaches. Furthermore, beyond data-driven assessment, our interest was also to contrast the produced regionalization process with the reality in the field. Thus, in February 2020 we carried out fieldwork in the Amazonian city known as Lago Agrio (the official name of the city is Nueva Loja) to qualitatively evaluate our results. With the field work we validated the potentiality of the generated Amazonian urban regions to better understand urban processes in the Amazon.

\section{Results}

We obtained a within-cluster sum of squares of 4709.79, and a between-cluster sum of squares of $11,496.20$. The ratio of between to total sum of squares obtained was 0.71 , which means that $71 \%$ of the total variance in the data set is explained by the clustering. Considering grouping 2702 urban zones (observations) in six clusters, this level of variance suggests a correct clustering quality. Additionally, the $\mathrm{p}$-value of the F-ratio (relationship of the between-cluster and the within-cluster mean squares) was 0.000 (very significant differences between clusters), which confirms the validity of the clusters (regions) produced.

Figure 2 shows the six Amazonian urban regions obtained and Table 1 presents the descriptive statistics of the used indicators for each urban region. The Amazonian urban region one corresponds to small cities and emerging urban zones of the center and north of the Ecuadorian Amazon, and the region extends from the province of Morona-Santiago to the province of Sucumbíos, including the provinces of Napo and Orellana. We understand emerging urban zones as small human settlements with limited urban infrastructure, "pioneer" urban zones in the advance of urban frontiers over agricultural areas and tropical forests. Urban region one does not have very irregular urban zones in terms of shape, and the number of streets varies with the size of the urban zone. Most of the urban zones have a luminosity less than $2 \mathrm{~W} / \mathrm{sr}$ (the zones practically do not generate light in the night) and are located less than $1 \mathrm{~km}$ from deforested areas. The distances from each zone to sources of oil and mining pollution markedly vary between the zones (very high standard deviation). However, most of the urban zones are located less than $5 \mathrm{~km}$ from oil pollution sources and further than $100 \mathrm{~km}$ from mining pollution sources.

The Amazonian urban region two includes 770 urban zones tan encompasses small cities and emerging urban zones of the south, in the provinces of Morona-Santiago and Zamora-Chinchipe. The fractal dimensions of these zones are very close to one (relatively compacted zones, not very irregular). Most of the zones do not have paved streets, have a luminosity less than $0.5 \mathrm{~W} / \mathrm{sr}$ (practically no luminosity), and are located less than $3 \mathrm{~km}$ from deforested areas, further than $100 \mathrm{~km}$ from oil pollution sources and less than $40 \mathrm{~km}$ from mining pollution sources.

The urban region three is formed by cities of the center-north and emerging zones distributed in all the provinces excepting Zamora-Chinchipe and includes the provincial capital cities of Tena, Puyo, and Macas. Most of the urban zones of this region have more irregular shapes than the average of all urban zones of the Ecuadorian Amazon, and have more paved streets in comparison with regions one and two, although most of the streets are concentrated in the cities of Puyo and Tena. The luminosity for this region is $14.37 \pm 111.63 \mathrm{~W} / \mathrm{sr}$, which means that there are very few zones as light as the city of Puyo (higher than 1000) while other zones (the majority) have very low or null luminosity. Most of the zones are located less than $1 \mathrm{~km}$ from deforested areas, less than $30 \mathrm{~km}$ from oil pollution resources, 
and further than $20 \mathrm{~km}$ from the closest mining pollution areas. Indeed, the closest urban zone from mining pollution is located at $13 \mathrm{~km}$, while there are some zones located at $0 \mathrm{~km}$ from oil pollution sources.

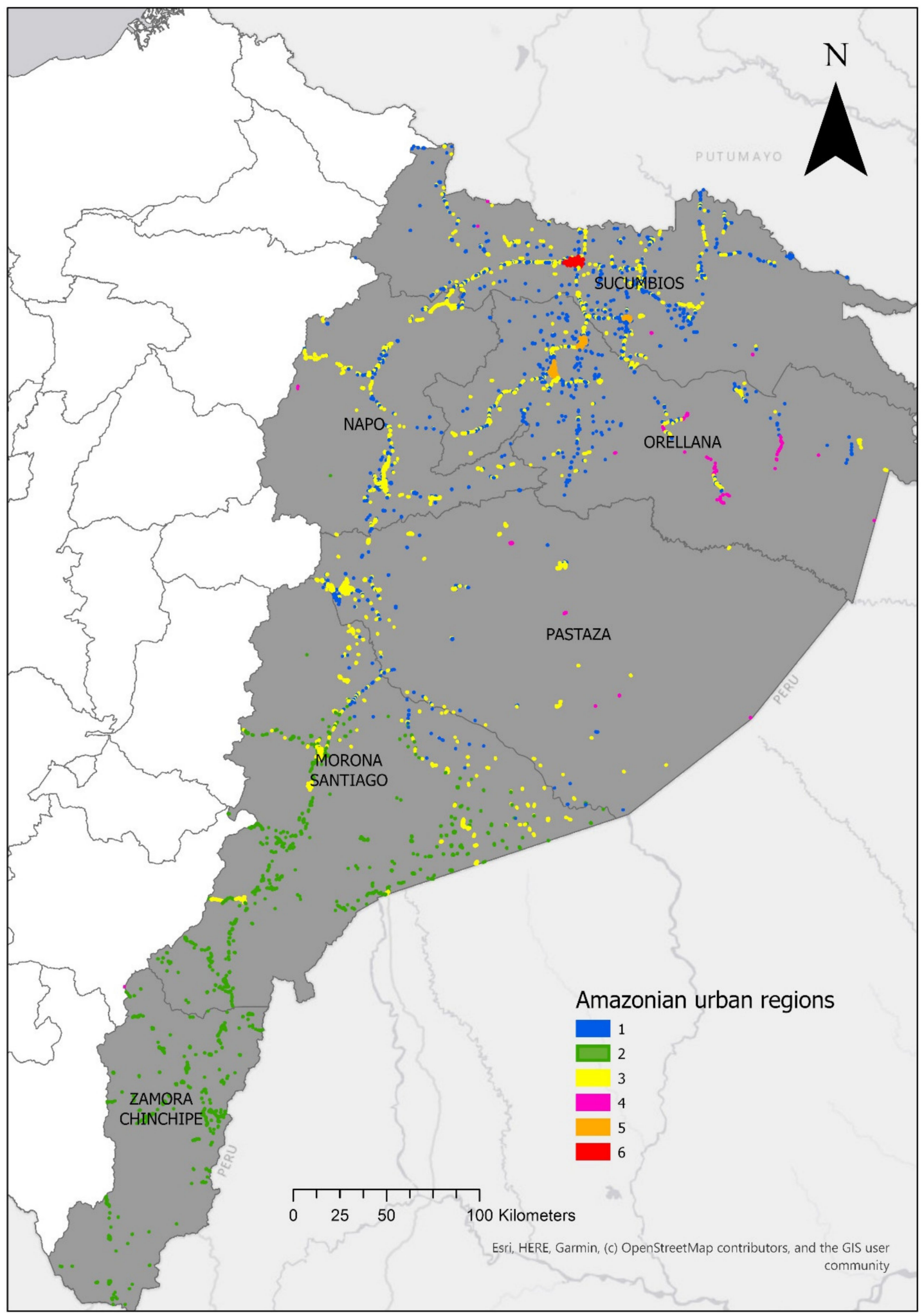

Figure 2. Amazonian urban regions of Ecuador. The outline widths of the urban zones are amplified to better visualize their locations. 
Table 1. Means and standard deviations of the used indicators for the calculated Amazonian urban regions, exempting region 6 (Lago Agrio), where simple indicators values are shown.

\begin{tabular}{|c|c|c|c|c|c|c|}
\hline Amazonian Urban Regions & $\begin{array}{c}\text { Fractal } \\
\text { Dimension }\end{array}$ & $\begin{array}{c}\text { Number of Paved } \\
\text { Streets }\end{array}$ & $\begin{array}{l}\text { Luminosity } \\
(\mathrm{W} / \mathrm{sr})\end{array}$ & $\begin{array}{c}\text { Distance to Deforested } \\
\text { Areas (m) }\end{array}$ & $\begin{array}{c}\text { Distance Oil } \\
\text { Pollution Source (m) }\end{array}$ & $\begin{array}{c}\text { Distance to Mining } \\
\text { Pollution Source }(\mathrm{m})\end{array}$ \\
\hline $\begin{array}{l}\text { Region 1: Small cities and emerging urban } \\
\text { zones of the center and north } \\
\qquad(N=1099)\end{array}$ & $1.05 \pm 0.02$ & $0.13 \pm 1.08$ & $5.77 \pm 66.39$ & $726.26 \pm 682.20$ & $14,305.15 \pm 23,191.81$ & $187,229.69 \pm 65,582.79$ \\
\hline $\begin{array}{l}\text { Region 2: Small cities and emerging urban } \\
\text { zones of the south } \\
(N=770)\end{array}$ & $1.07 \pm 0.03$ & $0.12 \pm 0.38$ & $1.62 \pm 11.03$ & $822.64 \pm 1047.05$ & $182,514.53 \pm 55,694.42$ & $31,999.38 \pm 30,947.22$ \\
\hline $\begin{array}{l}\text { Region 3: Cities of center-north and } \\
\text { emerging urban zones } \\
(N=765)\end{array}$ & $1.12 \pm 0.02$ & $1.06 \pm 7.51$ & $14.37 \pm 111.63$ & $668.57 \pm 767.88$ & $24,232.73 \pm 35,644.66$ & $163,842.15 \pm 66,557.01$ \\
\hline $\begin{array}{l}\text { Region 4: Emerging urban zones of the } \\
\text { north-east } \\
(N=64)\end{array}$ & $1.09 \pm 0.04$ & $0.00 \pm 0.00$ & $0.34 \pm 1.15$ & $9829.64 \pm 4235.05$ & $22,704.82 \pm 34,949.45$ & $254,830.17 \pm 61,052.30$ \\
\hline $\begin{array}{l}\text { Region 5: The three cities of the north } \\
\qquad(N=3)\end{array}$ & $1.13 \pm 0.03$ & $165.33 \pm 95.89$ & $4968.98 \pm 1790.54$ & $0.00 \pm 0.00$ & $0.00 \pm 0.00$ & $209,315.78 \pm 23,661.69$ \\
\hline $\begin{array}{c}\text { Region 6: Lago Agrio } \\
(N=1)\end{array}$ & 1.20 & 702 & 5532.27 & 0.00 & 0.00 & $201,749.92$ \\
\hline
\end{tabular}


The Amazonian urban region four encompasses 64 urban zones of the north-east, with an average fractal dimension of $1.09 \pm 0.04$, the zones do not have paved streets, and most of them do not have luminosity. The zones have an average distance to the closest deforested areas of $9829.64 \mathrm{~m} \pm 4235.05$, which suggests that this region is located nearest to conservation areas in our study. Some of its urban zones are adjacent to oil pollution sources but others are far away from these sources (some of them located further than $100 \mathrm{~km}$ ). Most of the region's zones are located further than $200 \mathrm{~km}$ from mining pollution sources.

Region five is formed by three Amazonian cities: El Coca, La Joya de los Sachas, and Shushufindi. Their fractal dimension departures from the Euclidean geometry and the three cities have more than 300 paved roads and a luminosity higher than $3000 \mathrm{~W} / \mathrm{sr}$. The three cities are adjacent to oil pollution resources and new deforested zones, and are located further than $180 \mathrm{~km}$ from mining pollution sources.

The Amazonian region six is the city of Lago Agrio, the capital city of the province of Sucumbíos. The city has an irregular shape (fractality of 1.2), 702 paved streets, a luminosity of $5532.27 \mathrm{~W} / \mathrm{sr}$, and is adjacent to new deforested zones. The city has oil pollution sources and is located further than $200 \mathrm{~km}$ from the closest mining pollution source.

Our results show that there is more complexity regarding urban regions in the northern Ecuadorian Amazon, an area mainly dedicated to activities related with the oil industry. Figure 3 depicts the urban regions one, three, five, and six that encompass this area. We consider this area of the Ecuadorian Amazon as an urban complex system where very different urban regions are located near each other. Figure 3 also shows satellite image revealing forest areas (dark green) and agriculture areas (light green). Urban regions one and three connect urban regions five and six across the main Amazon road. An important number of zones of the urban region one are located between agriculture areas.

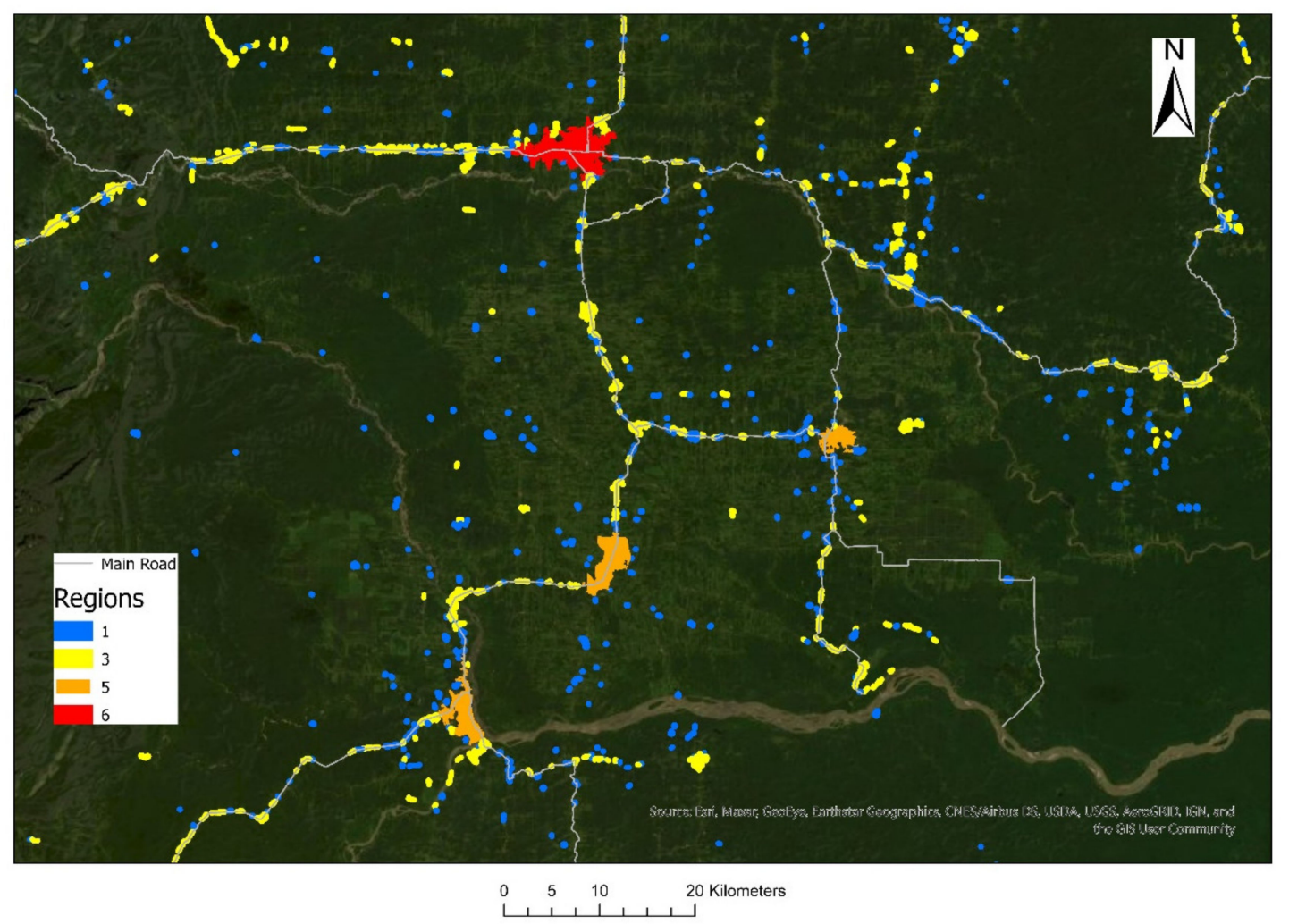

Figure 3. Urban regions 1, 3, 5, and 6: An Amazonian urban complex system. The outline widths of the urban zones are amplified to better visualize their locations. 
Figure 4 mainly depicts the urban region six, the city of Lago Agrio, as well as oil pollution sources, paved streets, and the main roads that connect Lago Agrio with other urban regions. The imagery displayed shows agricultural areas contrasting with forested areas.

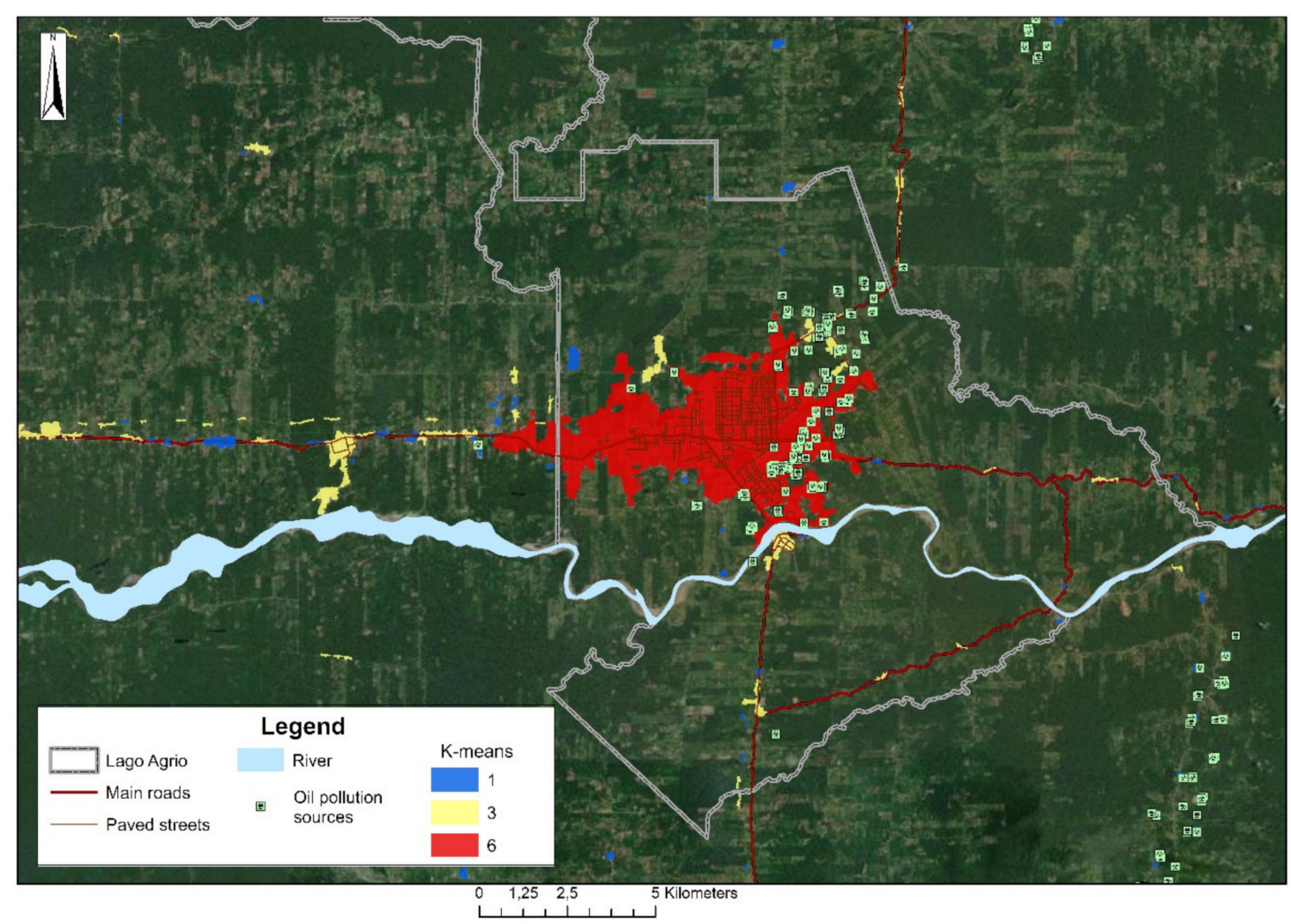

Figure 4. The urban region 6: The city of Lago Agrio.

Figure 5 depicts some pictures of our fieldwork. We consider that the Amazonian urban regions facilitate preliminary information on urban growth and consolidation, and in the fieldwork, we successfully tested the actual functionality of our geospatial approach. Urban region six precisely defines the urban continuum of a city (Lago Agrio) while urban region three represents disconnected areas from the city but with a strong urban consolidation: Figure 5 a shows a consolidated neighborhood located on the southern side of the river (disconnected with the city), and Figure $5 \mathrm{~b}$ depicts region three through a consolidated neighborhood located in the northeast of Lago Agrio and close to an oil platform. Urban region one represents emerging urban processes such as a new public housing development (Figure $5 \mathrm{c}$ ) and a recent private urbanization process (Figure $5 \mathrm{~d}$ ) located by a side of the main Amazonian road that connects Lago Agrio with the capital city of Ecuador, Quito. Regions one and three represent actual processes of urban expansion of Lago Agrio to the west. Region three is also associated with oil activities located in the northeast of this city, the region six. 


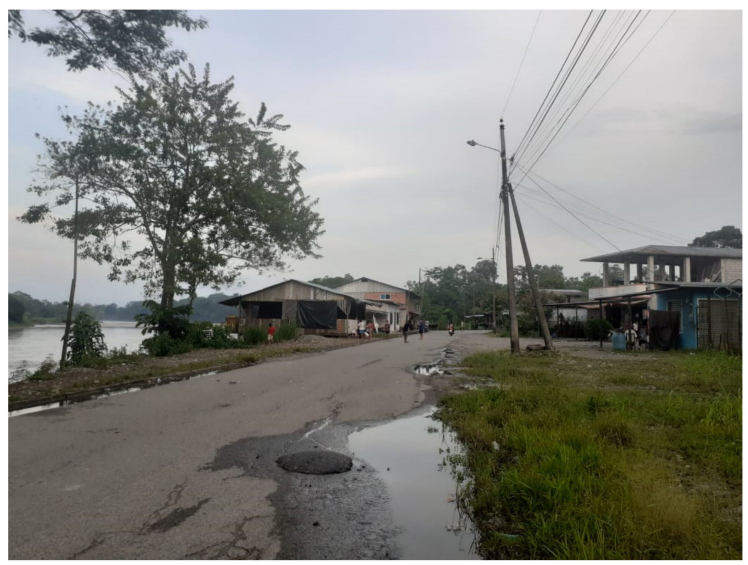

(a)

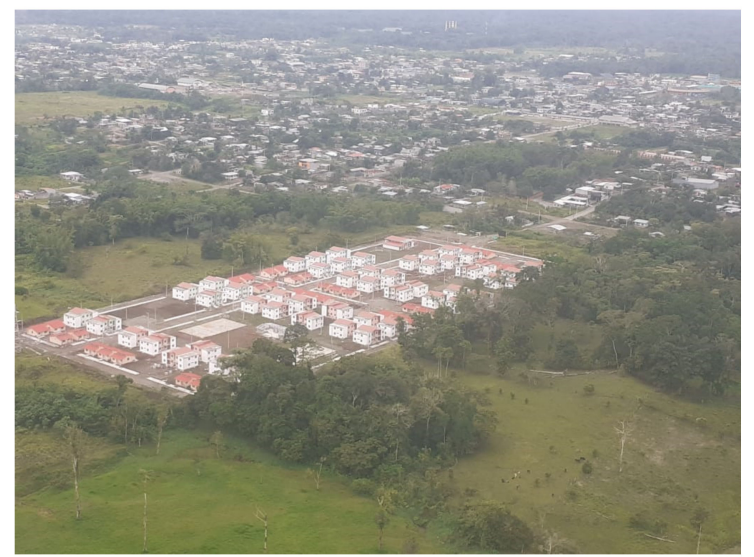

(c)

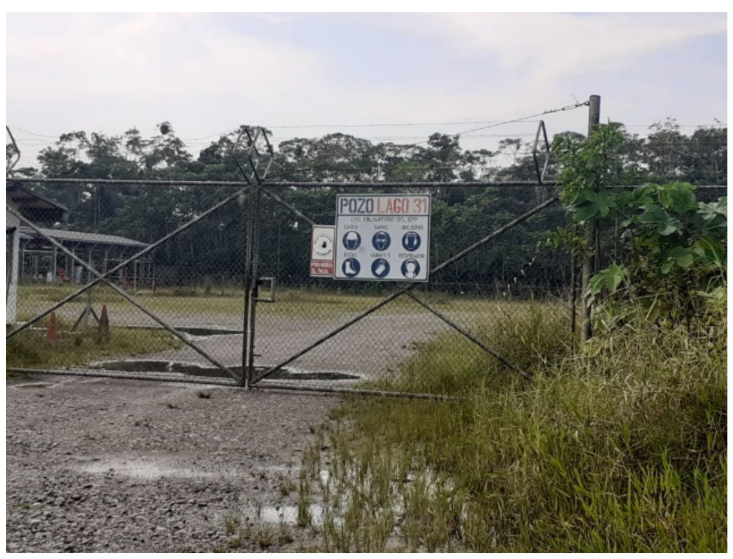

(b)

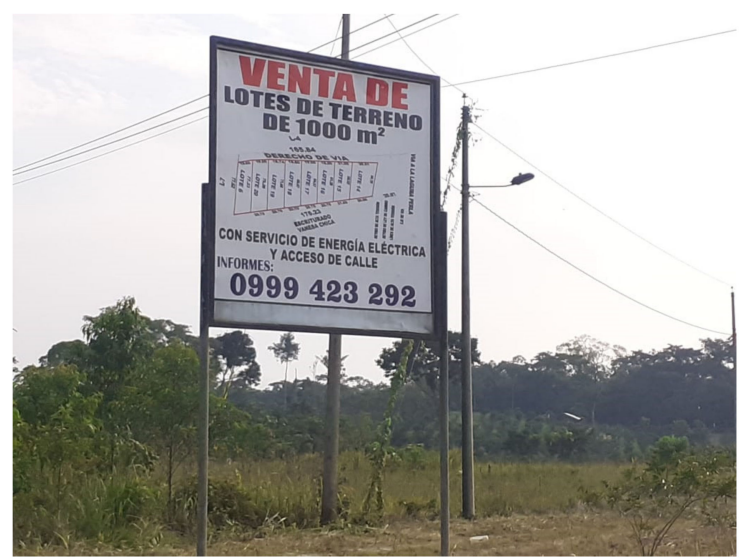

(d)

Figure 5. Urban realities associated with the urban regions calculated: (a) region 3: A consolidated neighborhood disconnected with the city of Lago Agrio; (b) region 3: A neighborhood located in the northeast of Lago Agrio and close to an oil platform; (c) region 1: A new public housing development; and (d) region 1: A recent private urbanization.

\section{Discussion}

To our knowledge, our study is the first to use a geospatial approach by applying key indicators of urban structure and context in the academic literature on the generation of Amazonian urban regions. We have identified six Amazonian urban regions for Ecuador. An advantage of the applied approach is the ability to consider urban structure and context indicators linked to Amazon realities such as oil pollution. It is also important to mention that the applied methodology recognizes the existence of urban regions that do not necessarily need to have adjacent urban zones. Thus, an Amazonian urban region is understood as a set of urban zones that are dispersed and that can be neighborhoods of zones of other urban regions. In other words, our regionalization model represents the complexity of urban systems in the Amazon that also include zones of different urban regions sharing similar characteristics.

It has been identified that distribution and clustering are fundamental characteristics of the urban form, where the form can be monocentric, polycentric, or decentralized sprawling [60]. In the Ecuadorian Amazon, urban regions one to four have decentralized sprawling, region five has a polycentric form of three centers, while region five is monocentric. However, we consider that even between these regions complex interactions exist at different scales. Thus, these regions could operate at intra-urban, inter-urban, and inter-regional scales [61], understanding intra-urban scale (meso-level) as polycentricity with dispersion and urban sub-centers [62,63], the inter-urban (macro-level) as the interaction between different conurbations [63], and the inter-regional scale, 
as extended metropolitan regions. However, for this study, the inter-regional scale refers to the Ecuadorian Amazon where the six different urban regions interact. Figures 2-5 facilitated an assessment of the multiscale implications of our findings. Although the Amazonian urban regions are adapted to understand the urban system at the scale of the Ecuadorian geographical region, we believe that the obtained regionalization can be interpreted at diverse scales of urban dynamics. For instance, several urban zones of region three located near Lago Agrio are dependent of oil activities and affected by oil pollution.

The dynamics of intra-urban and inter-urban regions show distinct zones with very low or null luminosity and very low or null presence of paved streets. These scenarios represent diverse conditions in Amazon cities: A lack of infrastructure yet forming sub-regional networks with high rates of urbanization [64]. In those cases, where urban sprawl has limited access to services, urban quality of life is affected. Furthermore, the presence of oil and mining industries in the Amazon creates an urban context that can worsen health outcomes and decrease quality of life for urban residents. In the Amazon geographical region, the urbanization process has also included indigenous populations. Although indigenous people in the Amazon traditionally live in rural environments, they are part of multiple realities and social responses that can symbolically and physically embrace urban life [47]. The regions one and four could be considered as indicative of this urban turning. For instance, region four is in indigenous territories, close to protected areas, but associated with the presence of roads used for resource extraction. This finding suggests an urbanization process that in the future may be overlapped with protected areas.

Mega-projects have largely influenced the urbanization process in the Ecuadorian Amazon. On the one hand, the northern Amazon (where Lago Agrio, the region six, is located) was the first place where oil exploitation in the Ecuadorian Amazon began (around 60 years ago). Consequently, it is now the most consolidated urban zone of the Ecuadorian Amazon. On the other hand, the northern Ecuadorian Amazon is part of the "Initiative for the Integration of the South American Regional Infrastructure". In these contexts, urbanization is expanding fast in this area of Ecuador. In the southern Ecuadorian Amazon where urban region two is presented, there are several small cities and emerging urban zones whose development and expansion are linked to mining mega-projects [48]. Mining is relatively new (30 years) in the Ecuadorian Amazon, and diverse urban dynamics are recently emerging and changing as the mining activities increase.

Most studies regarding Ecuadorian Amazon have been focused on the interactions between the Amazon and other geographical areas of the country such as the Highlands region (Sierra), and the connections between the Amazon and planetary processes $[65,66]$. Although these analyses are essential for explaining the spatial aspects and dynamics of the Amazon, they do not study intra-Amazonian formation. Our results describe for the first time the urban Amazon through the urban morphology, structure, and context: We present a mapping of the Amazon through the lens of the urban. Our approach also facilitates a first assessment of the urban expansion of Lago Agrio, and we consider this research as a pilot study in order to identify which urban areas of this city are facing notable changes.

One possible application of the methodology used in this research is the urban characterization of large study areas using diverse sources of information. The results obtained in the study represent a large Amazon urban regional system applying a geospatial approach, a truly little-studied perspective in the scientific literature regarding the Amazon. This work can be considered a groundbreaking proposal to visualize the urban complexity of the Amazon and facilitate deeper analyses of urban territorial processes occurring in the region. Furthermore, the present study can open up innovative conceptual discussions regarding the approaches to measure urbanization considering urban implosion/explosion. Our qualitative verification in the field also elucidates the correspondence between the geospatial and statistical-based urban regions and urban realities at the local level. There are several urban processes such as housing developments that are represented in the regionalization produced. All in 
all, this study demonstrates the advantage of using mixed methods to better understand the Amazon's urban topologies for more detailed knowledge of urban regionalization.

There are some limitations of our research that nevertheless illuminate future research needs. Although a geospatial approach has been applied to construct urban regions, it is important to mention that cities are functionally connected through cultural, social, institutional, and political links [63]. Thus, we believe that future research related with this study can incorporate to the geospatial approach qualitative information of socioeconomic and cultural aspects of urban residents. Our study did not incorporate a historical view of the urban regions. This kind of view would communicate a more complete understanding of the urban changes that could support the generation of prospecting scenarios of urbanization. To further our research, we plan to work on temporal dynamics of some cities of the Ecuadorian Amazon. The K-means algorithm is a fast, robust, and useful algorithm for clustering. However, other clustering algorithms may lead to different regionalization patterns than those we obtained in this study. Further study of clustering methods for urban regionalization would be of interest. Additionally, we consider that the indicators used in the K-means algorithm could be used to build an Amazonian urbanization index. To calculate this index, the definition of the indicators' weights will be crucial, and statistical approaches or multi-criteria methods may be applied for weighting $[67,68]$. Several other questions remain to be addressed in the urban regionalization addressed in this study. For instance, to what extent can the Amazonian urban regions support planners and decision makers to improve urban planning? What characteristics do new urban peripheries have? Who is living there? How can the dynamics of migration in the Amazon explain these emerging urban areas? We also consider that follow-up studies need to focus on the damaging effects of urban development in Amazon ecosystems. This is particularly important in cases where Amazon cities have no wastewater treatment systems and have poor systems of garbage collection and disposal. Continuing research on the urban representation of the Amazon appears fully justified because the presence of local and global processes that construct and de-construct human settlements configurations and livelihoods, dramatically influence local Amazonian ways of life. Our study is a first characterization of urban regions in the Amazon and offers a baseline to support approaches and solutions for sustainable urban processes. Spatial planning based on our regionalization approach can overcome traditional territorial planning perspectives in the Amazon based on the dichotomy of conservation areas/resources extraction. Furthermore, our regionalization may be used as a representation of spaces structure and spatial practices from a soft-space and fuzzy perspective of spatial planning [69]. Soft-spaces can include informal planning, and a fuzzy perspective means that forms of space and governance need to enable flexible policy responses [69]. The urban zones that make up each one of the Amazonian regions are in themselves a network of spaces that can be understood as functional planning areas. The six Amazonian regions are a polycentric regional system whose spatial configuration may be a functional space where different urban zones manifest diverse functions. These network and polycentric views of the Amazon can have important implications for the future urban planning of this exceptional part of the World.

Author Contributions: Pablo F. Cabrera-Barona conceptualized the study, performed most of the methodology and wrote most of the manuscript. Manuel Bayón contributed to the Introduction and Discussion sections and performed fieldwork. Gustavo Durán conceptualized the study and suggested some methodological approaches. Alejandra Bonilla contributed to the writing of some ideas of the Introduction and Methods sections. Verónica Mejía performed the calculations of the radiant intensity and contributed some writing of the methods section. All authors have read and agreed to the published version of the manuscript.

Funding: This research was funded by the Research Funds of FLACSO-Ecuador.

Acknowledgments: We thank the three reviewers and the Editor for taking the time to read the manuscript and provide constructive suggestions for improvements. Special thanks go to Ellen Gordon (University of Cambridge) for the most precise proofreading and excellent suggestions for language edits.

Conflicts of Interest: The authors declare no conflict of interest. 


\section{References}

1. Ruddick, S.; Peake, L.; Tanyildiz, G.S.; Patrick, D. Planetary urbanization: An urban theory for our time? Environ. Plan. D Soc. Space 2017, 36, 387-404. [CrossRef]

2. Brenner, N.; Schmid, C. Towards a new epistemology of the urban? City 2015, 151-182. [CrossRef]

3. Costa, S.M.; Brondízio, E.S. Cities Along the Floodplain of the Brazilian Amazon: Characteristics and Trends. In The Amazon Várzea: The Decade Past and the Decade Ahead; Pinedo-Vasquez, M., Ruffino, M.L., Padoch, C., Brondízio, E.S., Eds.; Springer: Dordrecht, The Netherlands, 2011; pp. 83-97. ISBN 978-94-007-0146-5.

4. Becker, B. Fronteira e urbanizaçao repensadas. Rev. Bras. Geogr. 1985, 47, 357-371.

5. Barbieri, A.F.; Monte-Mór, R.L.M.; Bilsborrow, R.E. Towns in the Jungle: Exploring Linkages between Rural-Urban Mobility, Urbanization and Development in the Amazon; Committee for International Cooperation in National Research in Demography (CICRED): Paris, France, 2007.

6. Ter Steege, H.; Pitman, N.C.A.; Phillips, O.L.; Chave, J.; Sabatier, D.; Duque, A.; Molino, J.-F.; Prévost, M.-F.; Spichiger, R.; Castellanos, H.; et al. Continental-scale patterns of canopy tree composition and function across Amazonia. Nature 2006, 443, 444-447. [CrossRef]

7. Bass, M.S.; Finer, M.; Jenkins, C.N.; Kreft, H.; Cisneros-Heredia, D.F.; McCracken, S.F.; Pitman, N.C.A.; English, P.H.; Swing, K.; Villa, G.; et al. Global Conservation Significance of Ecuador's Yasuní National Park. PLoS ONE 2010, 5, e8767. [CrossRef]

8. Csillik, O.; Kumar, P.; Mascaro, J.; O'Shea, T.; Asner, G.P. Monitoring tropical forest carbon stocks and emissions using Planet satellite data. Sci. Rep. 2019, 9, 17831. [CrossRef]

9. Soares-Filho, B.S.; Nepstad, D.C.; Curran, L.M.; Cerqueira, G.C.; Garcia, R.A.; Ramos, C.A.; Voll, E.; McDonald, A.; Lefebvre, P.; Schlesinger, P. Modelling conservation in the Amazon basin. Nature 2006, 440, 520-523. [CrossRef]

10. Davidson, E.A.; de Araújo, A.C.; Artaxo, P.; Balch, J.K.; Brown, I.F.; Bustamante, M.M.; Coe, M.T.; DeFries, R.S.; Keller, M.; Longo, M.; et al. The Amazon basin in transition. Nature 2012, 481, 321-328. [CrossRef]

11. Myers, N.; Mittermeier, R.A.; Mittermeier, C.G.; da Fonseca, G.A.B.; Kent, J. Biodiversity hotspots for conservation priorities. Nature 2000, 403, 853-858. [CrossRef]

12. Barbieri, A.F.; Carr, D.L. Gender-specific out-migration, deforestation and urbanization in the Ecuadorian Amazon. Glob. Planet. Chang. 2005, 47, 99-110. [CrossRef]

13. Mena, C.F.; Bilsborrow, R.E.; McClain, M.E. Socioeconomic Drivers of Deforestation in the Northern Ecuadorian Amazon. Environ. Manag. 2006, 37, 802-815. [CrossRef]

14. Ryder, R.; Brown, L.A. Urban-System Evolution on the Frontier of the Ecuadorian Amazon. Geogr. Rev. 2000, 90, 511-535. [CrossRef]

15. Kanai, J.M. On the Peripheries of Planetary Urbanization: Globalizing Manaus and its Expanding Impact. Environ. Plan. D Soc. Space 2014, 32, 1071-1087. [CrossRef]

16. Trindade Junior, S.-C.C. Pensando a Modernização do Território e a Urbanização Difusa na Amazônia. Mercator 2015, 14, 93-106. [CrossRef]

17. Padoch, C.; Brondizio, E.; Costa, S.; Pinedo-Vasquez, M.; Sears, R.R.; Siqueira, A. Urban Forest and Rural Cities: Multi-sited Households, Consumption Patterns, and Forest Resources in Amazonia. Ecol. Soc. 2008, 13, 2. [CrossRef]

18. Fanfani, D.; Duží, B. Urban bioregion concept: From theoretical roots to development of an operational framework in the European context. In Proceedings of the XXI Conferenza Nazionale SIU | CONFINI, MOVIMENTI, LUOGHI, Politiche e Progetti per Città e Territori in Transizione, Firenze, Italy, 6-8 June 2018.

19. Kloosterman, R.C.; Musterd, S. The Polycentric Urban Region: Towards a Research Agenda. Urban Stud. 2001, 38, 623-633. [CrossRef]

20. Nel·lo, O. Forma urbana y condición urbana en la obra de Francesco Indovina. In Economia, Società, Territorio. Riflettendo con Francesco Indovina; Fregolent, L., Sabino, M., Eds.; FrancoAngeli: Milan, Italy, 2013; pp. 164-171.

21. Brenner, N. Implosions/Explosions: Towards A Study of Planetary Urbanization; Jovis Verlag GmbH: Berlin, Germany, 2014; ISBN 9783868593174.

22. Lefebvre, H. La Revolución Urbana, 4th ed.; Alianza: Madrid, Spain, 1972; ISBN 9788420613789.

23. Brenner, N. Tesis sobre la urbanización planetaria. Nueva Soc. 2013, 243, 38-66. 
24. Indovina, F. ¿Es necesario esparcir la ciudad difusa? Las consecuencias sobre el gobierno del territorio de una clarificación terminológica. In Francesco Indovina: Del Analisis del Territorio al Gobierno de Ciudad; Nel·lo, O., Ed.; Icària Espacios Criticos: Barcelona, Spain, 2012.

25. Soja, E.W. Postmetrópolis: Estudios Críticos Sobre las Ciudades y las Regiones; Traficantes de Sueños: Madrid, Spain, 2008; ISBN 9788496453784.

26. Soja, E.W. Regional urbanization and the end of the metropolis era. In Cities in the 21st Century; Nel·lo, O., Mele, R., Eds.; Routledge: New York, NY, USA, 2016; pp. 71-89.

27. Rossi-Hansberg, E.; Wright, M.L.J. Urban Structure and Growth. Rev. Econ. Stud. 2007, 74, 597-624. [CrossRef]

28. Boeing, G. Urban spatial order: Street network orientation, configuration, and entropy. Appl. Netw. Sci. 2019, 4, 67. [CrossRef]

29. Batty, M.; Longley, P.A. The Fractal Simulation of Urban Structure. Environ. Plan. A Econ. Space 1986, 18, 1143-1179. [CrossRef]

30. Batty, M.; Longley, P.; Fotheringham, S. Urban Growth and Form: Scaling, Fractal Geometry, and Diffusion-Limited Aggregation. Environ. Plan. A Econ. Space 1989, 21, 1447-1472. [CrossRef]

31. Encarnação, S.; Gaudiano, M.; Santos, F.C.; Tenedório, J.A.; Pacheco, J.M. Urban Dynamics, Fractals and Generalized Entropy. Entropy 2013, 15, 2679-2697. [CrossRef]

32. Ferdous, F. The spatial analysis and morphological evolution of the 'Bazaar Streets' and urban structure of Dhaka city. URBAN Des. Int. 2012, 17, 206-220. [CrossRef]

33. Raimbault, J.; Perret, J. Generating urban morphologies at large scales. In Proceedings of the 9th Conference on Artificial Life, Newcastle, UK, 29 July-2 August 2019; pp. 1-9.

34. Encarnação, S.; Gaudiano, M.; Santos, F.C.; Tenedório, J.A.; Pacheco, J.M. Fractal cartography of urban areas. Sci. Rep. 2012, 2, 527. [CrossRef]

35. Santos, A.; Tabarelli, M. Distance from roads and cities as a predictor of habitat loss and fragmentation in the Caatinga vegetation of Brazil. Braz. J. Biol. 2002, 62, 897-905. [CrossRef]

36. Mejía, V. Morfología urbana y proceso de urbanización en Ecuador a través de la imagen satelital nocturna de la Tierra, 1992-2012. EURE 2020, 46, 191-214. [CrossRef]

37. Georg, I.; Blaschke, T.; Taubenböck, H. A Global Inventory of Urban Corridors Based on Perceptions and Night-Time Light Imagery. ISPRS Int. J. Geo-Inform. 2016, 5, 233. [CrossRef]

38. Amaral, S.; Monteiro, A.M.V.; Camara, G.; Quintanilha, J.A. DMSP/OLS night-time light imagery for urban population estimates in the Brazilian Amazon. Int. J. Remote Sens. 2006, 27, 855-870. [CrossRef]

39. Sutton, P.; Roberts, D.; Elvidge, C.; Baugh, K. Census from Heaven: An estimate of the global human population using night-time satellite imagery. Int. J. Remote Sens. 2001, 22, 3061-3076. [CrossRef]

40. Checa, J.; Nel·lo, O. Urban Intensities. The Urbanization of the Iberian Mediterranean Coast in the Light of Nighttime Satellite Images of the Earth. Urban. Sci. 2018, 2, 115. [CrossRef]

41. Stathakis, D.; Baltas, P. Seasonal population estimates based on night-time lights. Comput. Environ. Urban Syst. 2017, 68, 133-141. [CrossRef]

42. Walsh, S.J.; Messina, J.P.; Mena, C.F.; Malanson, G.P.; Page, P.H. Complexity theory, spatial simulation models, and land use dynamics in the Northern Ecuadorian Amazon. Geoforum 2008, 39, 867-878. [CrossRef]

43. Richards, P.; VanWey, L. Where Deforestation Leads to Urbanization: How Resource Extraction Is Leading to Urban Growth in the Brazilian Amazon. Ann. Assoc. Am. Geogr. 2015, 105, 806-823. [CrossRef]

44. Finer, M.; Jenkins, C.N.; Pimm, S.L.; Keane, B.; Ross, C. Oil and Gas Projects in the Western Amazon: Threats to Wilderness, Biodiversity, and Indigenous Peoples. PLoS ONE 2008, 3, e2932. [CrossRef]

45. Finer, M.; Babbitt, B.; Novoa, S.; Ferrarese, F.; Pappalardo, S.E.; De Marchi, M.; Saucedo, M.; Kumar, A. Future of oil and gas development in the western Amazon. Environ. Res. Lett. 2015, 10, 024003. [CrossRef]

46. Rudel, T.K.; Bates, D.; Machinguiashi, R. A Tropical Forest Transition? Agricultural Change, Out-migration, and Secondary Forests in the Ecuadorian Amazon. Ann. Assoc. Am. Geogr. 2002, 92, 87-102. [CrossRef]

47. Alexiades, M.; Peluso, D. La urbanización indígena en la Amazonia. Un nuevo contexto de articulación social y territorial. Gaz. Antropol. 2016, 32, 1-22.

48. Bayón, M. Una mirada de la Amazonía a través de la urbanización. In Geografía Crítica para Detener el Despojo de los Territorios; Abya-Yala: Quito, Ecuador, 2019; pp. 191-205. ISBN 978-9942-09-643-2.

49. Wilson, J.; Bayón, M. La Selva de los Elefantes Blancos: Megaproyectos y Extractivismos en la Amazoniía Ecuatoriana; Abya Yala: Quito, Ecuador, 2017; ISBN 9789942094483. 
50. Jarrín-Valladares, P.; Tapia, L.; Zamora, G. Demografía y transformación territorial: Medio siglo de cambio en la región amazónica de Ecuador/ Demography and territorial transformation: Half a century of change in the Amazonian Region of Ecuador. Eutopía Rev. Desarro. Económico Territ. 2017, 81. [CrossRef]

51. Carrión, F. Las ciudades intermedias en el contexto de la urbanización ecuatoriana: Un intento de interpretación. Rev. Interam. Planif. 1994, XVIII, 19. [CrossRef]

52. INEC. Censo de Población y Vivienda; INEC: Quito, Ecuador, 2010.

53. INEC. Proyecciones Poblacionales; INEC: Quito, Ecuador, 2020.

54. MAE Infraestructura de Datos Espaciales. Available online: http://ide.ambiente.gob.ec/mapainteractivo/ (accessed on 22 January 2020).

55. Fragstats Shape Metrics. Available online: http://www.umass.edu/landeco/research/fragstats/documents/ Metrics/ShapeMetrics/SHAPEMETRICS.htm (accessed on 23 January 2020).

56. Liao, L.B.; Weiss, S.; Mills, S.; Hauss, B. Suomi NPP VIIRS day-night band on-orbit performance. J. Geophys. Res. Atmos. 2013, 118, 705-712. [CrossRef]

57. AssunÇão, R.M.; Neves, M.C.; Câmara, G.; Da Costa Freitas, C. Efficient regionalization techniques for socio-economic geographical units using minimum spanning trees. Int. J. Geogr. Inform. Sci. 2006, 20, 797-811. [CrossRef]

58. Jain, A.K. Data clustering: 50 years beyond K-means. Pattern Recognit. Lett. 2010, 31, 651-666. [CrossRef]

59. Jain, A.K.; Dubes, R.C. Algorithms for Clustering Data; Prentice Hall: Upper Saddle River, NJ, USA, 1988.

60. Tsai, Y.-H. Quantifying Urban Form: Compactness versus "Sprawl”. Urban. Stud. 2005, 42, 141-161. [CrossRef]

61. Davoudi, S. EUROPEAN BRIEFING: Polycentricity in European spatial planning: From an analytical tool to a normative agenda. Eur. Plan. Stud. 2003, 11, 979-999. [CrossRef]

62. Curtis, C. Network City: Retrofitting the Perth Metropolitan Region to Facilitate Sustainable Travel. Urban. Policy Res. 2006, 24, 159-180. [CrossRef]

63. Georg, I.; Blaschke, T.; Taubenböck, H. New spatial dimensions of global cityscapes: From reviewing existing concepts to a conceptual spatial approach. J. Geogr. Sci. 2016, 26, 355-380. [CrossRef]

64. Costa, S.M.; Brondízio, E.S. Dependência Inter-urbana entre as Cidades Amazônicas: Crescimento Urbano, Deficiências em Infra-estrutura e Redes Sociais. Redes. Rev. Desenvol. Reg. 2009, 14, 211-234.

65. Wilson, J.; Bayón, M. Concrete Jungle: The Planetary Urbanization of the Ecuadorian Amazon. Hum. Geogr. 2015, 8, 1-23. [CrossRef]

66. Erazo, N. La Red Urbana Amazónica: Análisis Multiescalar de la Dinámica de Urbanización; Facultad Latinoamericana de Ciencias Sociales: De Guatemala, Guatemala, 2017.

67. Cabrera-Barona, P.; Wei, C.; Hagenlocher, M. Multiscale evaluation of an urban deprivation index: Implications for quality of life and healthcare accessibility planning. Appl. Geogr. 2016, 70, 1-10. [CrossRef]

68. Cabrera-Barona, P.; Blaschke, T.; Gaona, G. Deprivation, Healthcare Accessibility and Satisfaction: Geographical Context and Scale Implications. Appl. Spat. Anal. Policy 2017,1-20. [CrossRef]

69. Allmendinger, P.; Haughton, G. Spatial Planning, Devolution, and New Planning Spaces. Environ. Plan. C Gov. Policy 2010, 28, 803-818. [CrossRef]

(C) 2020 by the authors. Licensee MDPI, Basel, Switzerland. This article is an open access article distributed under the terms and conditions of the Creative Commons Attribution (CC BY) license (http://creativecommons.org/licenses/by/4.0/). 